\title{
“Foi QUANDO ESTAVA ACABANDO \\ O TEMPO DOS ESCRAVOS”: \\ DEVOÇÃO, REDES FAMILIARES E CONFLITOS \\ NAS ÚLTIMAS DÉCADAS DA ESCRAVIDÃO \\ eM Minas Gerais
}

\author{
Lívia Nascimento Monteiro (iD \\ Universidade Federal de Alfenas
}

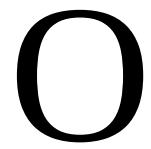

frio anuncia a chegada da festa. Maio ainda é outono, mas o "frio da festa de maio" lembra que nos últimos dias desse mês haverá danças, procissões, missas, batuques, bailes e muita festança. O calor da fogueira aquece e os congadeiros-moçambiqueiros protegem o cortejo do rei e rainha congos, dos príncipes, princesas e de toda a corte real. A cidade é tomada por devoção, sons, performances, barracas, turistas, câmeras fotográficas e celulares que tentam captar cada movimento sincronizado, ritmado e cantado.

É dessa maneira que, por mais de noventa anos, a festa de Congada e Moçambique de Piedade do Rio Grande, interior de Minas Gerais, revive o passado no presente. A festa se tornou uma reconciliação com o passado traumático escravista e uma celebração pela liberdade, através dos rituais, das músicas e dos passos executados pelos mais de cem homens negros dançadores congadeiros-moçambiqueiros. ${ }^{1}$

1 As análises propostas neste artigo compõem parte da tese de doutorado "A Congada é do mundo e da raça negra: memórias da escravidão e da liberdade nas festas de Congada e Moçambique em Piedade do Rio Grande-MG (1873-2015)”, defendida no Programa de Pós-Graduação em História da Universidade Federal Fluminense em 2016, com a orientação da professora Martha Abreu. 
As memórias da escravidão e da liberdade estão nos versos cantados, nos passos executados e na devoção aos santos. Dessa forma, a intenção deste trabalho é demonstrar que o legado deixado por algumas famílias de escravizados e libertos na segunda metade do século XIX em Minas Gerais para seus descendentes se transformou num verdadeiro espetáculo da cultura negra na contemporaneidade, que são as festas de Reinados, Reisados ou Congadas, como são popularmente conhecidas. ${ }^{2}$

As congadas existem em praticamente todo o estado de Minas Gerais. Através de cortejos, reis e rainhas congos tomam as ruas das cidades, com danças, músicas e a devoção aos diferentes santos católicos que se mesclam aos códigos que congregam elementos das religiões de matriz afro-brasileira. Muitos ternos (que são os diferentes grupos que compõem o Reinado) são heranças das irmandades negras de Nossa Senhora do Rosário, Santa Efigênia e São Benedito do período colonial e imperial. ${ }^{3}$

A imposição da cultura religiosa católica portuguesa aos africanos escravizados no Brasil não foi concebida sem as concepções próprias das identidades africanas, especialmente para os povos bantos, que já conheciam a linguagem do catolicismo africano no seu próprio continente. Esse novo contexto político favoreceu o surgimento do catolicismo negro nas Américas e as festas dos "reis negros" podem ser entendidas como o encontro das culturas africanas e ibérica, no contexto da escravidão. ${ }^{4}$

2 Existem as festividades do Reinado - estrutura mais ampla e complexa, que abrange as guardas, os ternos e contempla vários rituais de devoção e festa - e a Congada, que além de se referir à festa, também dá nome às guardas do Congo, como acontece em Piedade. De acordo com Paulo Dias, “existem as guardas de congo, de moçambique, de marujo, de catopé, de caboclinho, de vilão e outros. Cada um desses grupo canta, dança e toca um tipo de música, com instrumentos diferentes, além de usar vestimentas específicas [...]. O Reinado é um grupo de pessoas que se organiza em torno de uma hierarquia formada por reis, rainhas e capitães, cumprindo determinadas funções rituais nos festejos, nos quais seus ancestrais e os santos de devoção são homenageados”. Paulo Dias, “A outra festa negra” in István Jancsó e Íris Kantor (orgs.), Festa: cultura e sociabilidade na América Portuguesa, (São Paulo: Hucitec; Edusp; Fapesp; Imprensa Oficial, 2001), p. 14.

3 Patrícia Trindade Maranhão Costa, As raízes da congada: a renovação do presente pelos Filhos do Rosário, Curitiba: Appris, 2012, p. 33.

4 Marina de Mello e Souza, Reis negros no Brasil escravista: história da festa da coroação do rei Congo, Belo Horizonte: UFMG, 2002, p. 45. 
Em Piedade do Rio Grande, a Associação de Congada e Moçambique promove oficialmente desde a década de 1920 a Festa de Maio - como é carinhosamente chamada a festa da Associação - que tem como enredo central a aparição e retirada de Nossa Senhora do Rosário da gruta e sua ida para a casa santa junto aos negros, com as performances que acionam as memórias da escravidão e da liberdade.

As performances realizadas na festa "seguram as guardas", 5 ou seja, o cortejo somente prossegue se tudo estiver adequado. Os movimentos executados pelos congadeiros-moçambiqueiros de Piedade, ao levar a rainha até a casa santa - a Igreja do Rosário -, representam o episódio das narrativas fundadoras das festas de Congadas em Minas Gerais. A corte, composta pelo rei e pela rainha congo e por príncipes e princesas, são escolhidos entre os membros congadeiros-moçambiqueiros e pela hierarquia dos ternos, o capitão lidera os dançadores que escoltam o cortejo real.

Figura 1

Congadeiros fazendo guarda, registrados na Festa de Maio de 2019

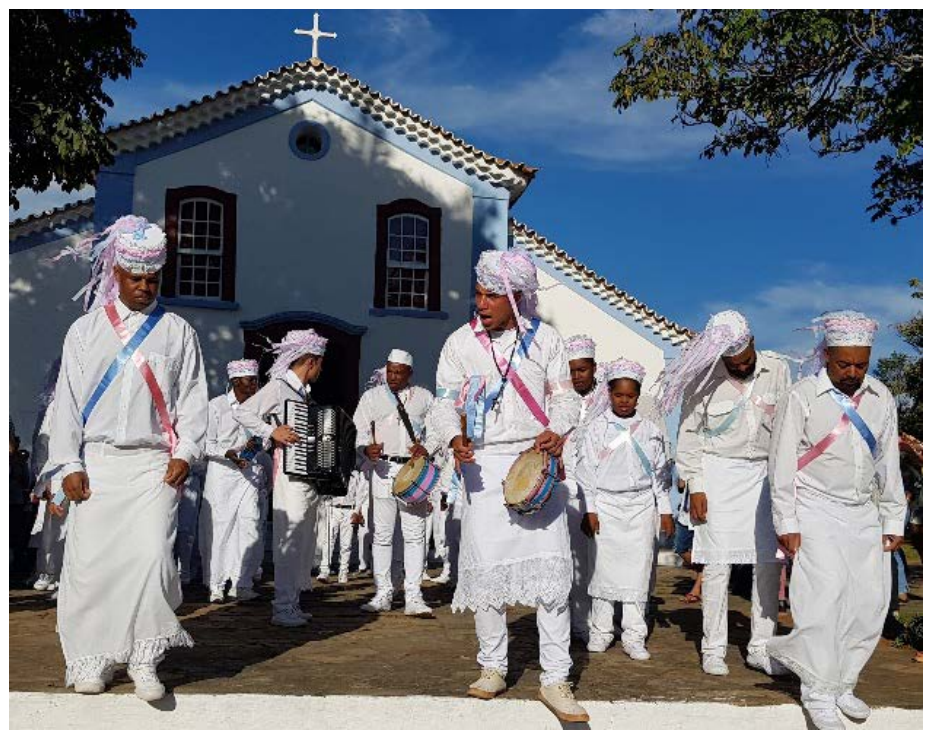

5 Entrevista concedida por João Damasceno de Faria em 30 maio 2012. 
Figura 2

Rei e rainha congo, reis eleitos e príncipes da Festa de Maio de $2019^{6}$

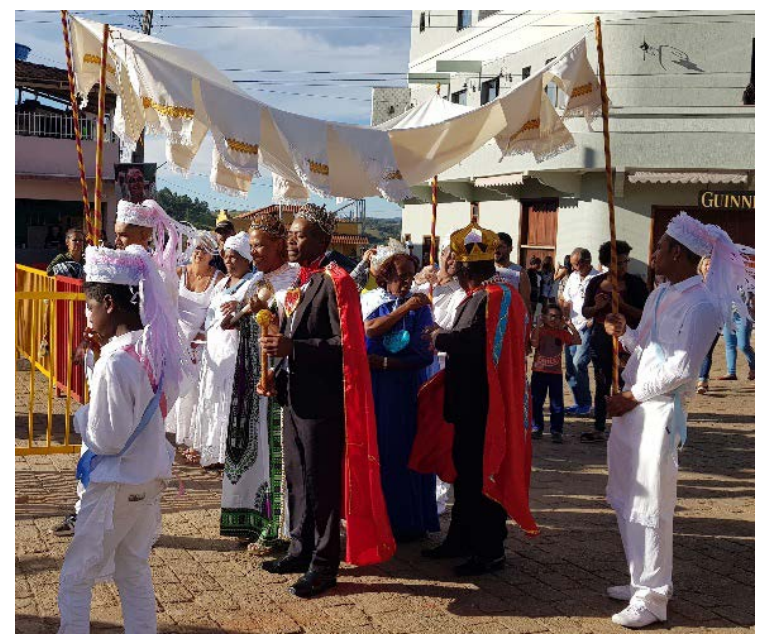

Este artigo analisa uma geração de algumas famílias de escravizados e libertos que foram responsáveis por fundar a Associação de Congada e Moçambique de Piedade do Rio Grande - especialmente aquela dos primeiros capitães José Venâncio Lima e João Manoel da Cruz, conhecido como João Lotera - e as redes familiares, os conflitos e as devoções ligadas à Irmandade do Rosário em que estavam submersos nas últimas décadas do século XIX em Minas Gerais.

Os caminhos metodológicos seguiram as pistas deixadas pelas memórias dos descendentes das famílias fundadoras. Por meio de nomes de pais, avós e familiares citados nas entrevistas orais realizadas entre 2012 e 2014 com os descendentes dessas famílias, ${ }^{7}$ foi possível localizar

6 Fotografias de Angélica Barros. Piedade do Rio Grande, Minas Gerais, Brasil, 2019.

7 Todas as entrevistas orais analisadas neste artigo foram produzidas durante minha pesquisa de doutorado, que buscou analisar, de maneira geral, as memórias e narrativas congadeiras-moçambiqueiras na cidade de Piedade do Rio Grande. As entrevistas estão depositadas no acervo do Laboratório de História Oral e Imagem (Labhoi/UFF), com a pesquisadora e com o presidente da Associação de Congada e Moçambique de Piedade do Rio Grande. 
os registros de batismo, inventários e testamentos para compor a genealogia familiar dos capitães fundadores da Associação de Congada e Moçambique de Piedade do Rio Grande, as relações com a Irmandade do Rosário de Ibertioga, cidade vizinha de Piedade, e os conflitos e incertezas gerados pelo fim do escravismo em Minas Gerais.

Pelas entrevistas orais, o “aprendizado” de ser congadeiro-moçambiqueiro do grupo de Piedade é explicado por meio dos laços com os grupos de Congada de Barroso e Ibertioga, cidades vizinhas. Essa forma de narrar a fundação da Congada e Moçambique é transmitida de geração em geração. Questionei, assim, os pontos de contato entre as duas congadas e a existência de um elo com o passado escravista.

A princípio, não esperava encontrar nos inventários dos antigos senhores escravistas da região de Piedade algum dado sobre tais pontos de contato. ${ }^{8}$ Entretanto, quando o dono da Fazenda da Vargem faleceu em 1862, dentre os muitos bens deixados aos herdeiros, havia também as dívidas, e uma delas intrigante: Justino faleceu devendo um conto e

8 Ao mapear as principais fazendas escravistas na região, com o intuito de localizar os antepassados escravizados da geração fundadora da festa, não esperava descobrir, por meio dessas memórias e da documentação dos arquivos, as histórias dos meus próprios antepassados escravistas, pois sou natural de Piedade do Rio Grande. Vale ressaltar o quanto foi difícil trabalhar com essas descobertas, afinal, a história da minha família branca e ex-senhorial - passou a permear muitas páginas desse trabalho, no entrelaço com o passado congadeiro-moçambiqueiro. O casal Justino Fagundes do Nascimento e Maria Baptista Teixeira, retratados neste artigo, são meus tataravôs, antigos proprietário da fazenda da Vargem - local onde passei minha infância. Local também de recordações tristes e encantadas, recheadas de histórias de fantasmas, assombrações e também de encontros familiares. Eram os possíveis encontros com as minhas "zonas de penumbras” - lembranças e tradições familiares misturadas com o que aprendemos sobre um período histórico -, que Hobsbawn conceituou. Desse modo, pedi licença aos antepassados escravizados da fazenda da Vargem e a todos os congadeiros-moçambiqueiros para narrar partes de suas histórias de vida e tentar buscar os elos perdidos como forma de reparação do passado no tempo presente, problematizando sempre o meu lugar de fala, como Djamila Ribeiro nos ensina, e me posicionando enquanto pesquisadora branca que pesquisa as festas negras e não sente a dor do racismo, mas que reconhece os privilégios da branquitude na sociedade brasileira e trabalha por uma educação antirracista cotidianamente. Djamila Ribeiro, O que é lugar de fala? Belo Horizonte: Letramento, 2017. Eric Hobsbawn e Terence Ranger, A invenção das tradições, Rio de Janeiro: Paz e Terra, 1989. 
duzentos mil réis à Irmandade do Rosário de Ibertioga. ${ }^{9}$ Isto indicava uma ligação entre a Congada e Moçambique de Piedade com alguma Irmandade do Rosário do século XIX.

As duas famílias escravas dos antepassados dos capitães congadeiros-moçambiqueiros pertenceram ao senhor Justino. Tanto a família do primeiro capitão, José Venâncio, como a do segundo, João Lotero, tinham ligações com a família de Justino e seus aparentados. Portanto, a dívida à Irmandade do Rosário de Ibertioga forneceu pistas sobre a ligação entre os antepassados congadeiros-moçambiqueiros de Piedade e os de Ibertioga. A Figura 3 apresenta os fundadores da Associação de Congada e Moçambique de Piedade na década de $1940 .{ }^{10}$ No canto superior esquerdo, em pé e com a viola, está o segundo capitão João Lotera e ao lado o primeiro capitão, José Venâncio.

Figura 3

Fundadores da Associação de Congada e Moçambique de Piedade do Rio Grande-MG, anos $1940^{11}$

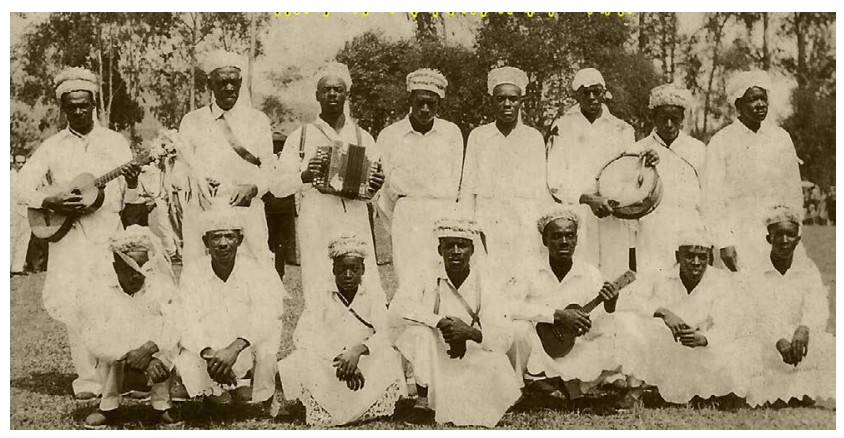

9 Arquivo da sede do Instituto do Patrimônio Histórico e Artístico Nacional (Iphan) em São João del Rei - MG, fundo 45, cx. 174, Inventário de Justino Fagundes do Nascimento, 24 jul. 1862.

10 Em 1928, a ata de fundação da Associação de Congada e Moçambique de Piedade do Rio Grande foi registrada em cartório, com a assinatura de mais de trinta nomes de homens negros com a liderança de José Venâncio Lima e João Manoel da Cruz, primeiros capitães do grupo, analisados nesse artigo. A ata encontra-se sob guarda e posse da Associação de Congada e Moçambique de Piedade do Rio Grande, MG, e transcrita também no livro: Giane de Carvalho Menezes, Congada e Moçambique em Piedade do Rio Grande: passos de folia e fé, Volta Redonda: Editora CSN, 2008.

11 A fotografia compõe o acervo de fotos e documentos da Associação de Congada e Moçambique de Piedade do Rio Grande, MG. 


\section{Por escravizados e libertos: histórias da última geração do cativeiro em Piedade do Rio Grande}

O pequeno arraial de Piedade, localizado no campo das vertentes, próximo ao sul de Minas Gerais, remonta ao século XVIII, período da criação do curato de Nossa Senhora da Piedade, com a fundação da igreja datada de 1748. Entre o fim do século XVIII e meados do século XIX, a região se manteve pelas trocas econômicas com as vilas mineradoras vizinhas, São João del Rei e São José del Rei, atual Tiradentes.

Em 1831, o então distrito de Nossa Senhora da Piedade do Rio Grande, termo da Vila de São João del Rei, contava com 157 fogos (casas), 1.290 habitantes, dos quais 674 livres e 616 cativos. ${ }^{12}$ Impressiona a proporção de cerca de $48 \%$ da população como escrava. Carvalho atenta para o fato de que na comarca do Rio das Mortes, à qual pertencia Piedade, “a porcentagem de escravos era de 33\%, próxima à média brasileira. A média de escravos por fogo ficava em torno de dez, um pouco mais alta do que a média mineira”. O censo de 1872 apontou Minas Gerais como a província com maior número de escravizados do país. Em 1885, a população cativa da província somava 276.275 indivíduos, diminuindo para 191.952 em $1887 .{ }^{13}$

Na região circunvizinha a Piedade, no século XIX, as atividades produtivas dependiam, substancialmente, da mão de obra escrava. São João del Rei foi marcada pela produção agropecuária e ficou conhecida como “o celeiro das Gerais”, devido à importância que teve no abastecimento de outras regiões. Conforme esclarece Graça Filho, no século XIX desenvolveu-se nessa região um intenso comércio, com a convivência de médias e pequenas fazendas escravistas de importante

12 Arquivo Público Mineiro (APM), Belo Horizonte, fundo 34, cx. 6, doc. 18, Relação dos Habitantes da Aplicação de N. S. da Piedade do Rio Grande, 20 maio 1831.

13 Luis Gustavo Santos Cota, "Ave, libertas: abolicionismos e luta pela liberdade em Minas Gerais na última década da escravidão”, Tese (Doutorado em História), Universidade Federal Fluminense, Niterói, 2013, p. 27. 
desempenho econômico, favorecendo a permanência do maior número de escravizados na província. ${ }^{14}$

Em Piedade no final do século XIX, as fazendas de gado, milho e feijão permaneceram ativas, mesmo após a abolição. As famílias escravas e libertas que viveram o fim da escravidão nessas fazendas souberam utilizar estratégias diversas para enfrentar os desafios desse período. Foi possível perceber isso através da reconstrução da história familiar e da genealogia dos dois primeiros capitães da Congada e Moçambique, membros da geração que deixou como legado para seus familiares uma importante instituição cultural no século XX, marcada pelas memórias do passado escravista até o tempo presente. ${ }^{15}$

14 Afonso Alencastro Graça Filho, A princesa do Oeste e o mito da decadência de Minas Gerais. São João Del Rei (1831 - 1888), São Paulo: Annablume, 2002, p. 14.

15 Thomas C. Holt, Rebecca J. Scoot e Frederick Cooper, em livro referência sobre o pós-abolição em diferentes locais do Atlântico Negro, preocupam-se em debater sobre quais seriam as fronteiras e as temporalidades adequadas aos estudos sobre as experiências da escravidão e da liberdade. Geralmente, os trabalhos sobre o período do pós-emancipação remetem ao fim da escravidão e não têm data limite para acabar, como afirmam os autores (Frederick Cooper, Thomas Cleveland Holt e Rebecca Jarvis Scott, Além da escravidão: investigações sobre raça, trabalho e cidadania em sociedades pós-emancipação, Trad. Maria Beatriz de Medina, Rio de Janeiro: Civilização Brasileira, 2005). O processo da abolição é de difícil datação exata, o mês de maio de 1888 poderia ser tomado como ponto de partida ao chamado imediato pós-abolição, porém outras datas significativas do processo de emancipação no Brasil, como 1831, 1850 ou 1871 poderiam ser esquecidas. Assim, neste trabalho, considero que o período analisado compreende, para além do recorte fixo em datas, o recorte das trajetórias das famílias negras estudadas, que desde os últimos anos da escravidão, passando pelo imediato pós-abolição e até os dias atuais, são protagonistas nas festas congadeiras-moçambiqueiras na cidade. Vale pontuar também que este trabalho faz parte de uma corrente de pesquisas que encontraram, a partir das memórias de diferentes famílias negras e do cruzamento com a documentação de arquivos, histórias da escravidão e do pós-abolição em diferentes territórios do Brasil. Ver: Rodrigo Weimer, Felisberta e sua gente: consciência histórica e racialização em uma família negra no pós-emancipação rio-grandense, Rio de Janeiro: Editora FGV. Martha Abreu, Hebe Mattos e Milton Guran, "Por uma história pública dos africanos escravizados no Brasil”, Estudos Históricos (Rio de Janeiro), v. 27, (2014), pp. 255-273. Walter Fraga Filho, Encruzilhadas da Liberdade: histórias de escravos e libertos na Bahia (1870-1910), Campinas: Editora da Unicamp, 2006. Flávio dos Santos Gomes e Olívia Maria Gomes da Cunha, "Introdução” in Flávio dos Santos Gomes e Olívia Maria Gomes da Cunha, Quase-cidadão: histórias e antropologias da pós-emancipação no Brasil (Rio de Janeiro: Editora da FGV, 2007). 
O ano era 1873. Na ermida da Fazenda da Vargem, foi batizado José Venâncio Lima, que passou parte de sua infância e adolescência nessas terras, ainda durante a escravidão. Com a abolição, trabalhou em fazendas da região. Casou-se com Maria José de Faria, filha de Maria Iria e Militino, ambos escravizados da Fazenda do Tejuco, vizinha à Fazenda da Vargem. Nas palavras das filhas do casal, Maria Emerenciana Silva, Adalgisa Lima e Lourdes Lima, com, respectivamente, 88, 85 e 77 anos em 2012, seus pais “pegaram a escravidão, mas meu pai nasceu ventre livre”. ${ }^{16}$

Figura 4

Ana, Adalgiza, Lourdes e Maria Emerenciana com o retrato de José Venâncio Lima ${ }^{17}$

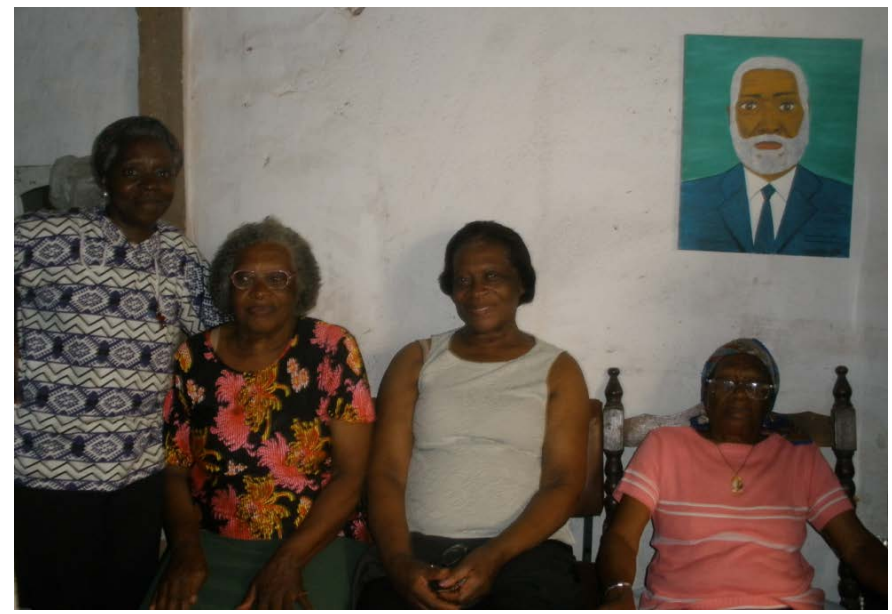

A Figura 5 demonstra os enlaces da família do primeiro capitão José Venâncio Lima, que faleceu com 102 anos em 1975 na cidade de São Paulo. ${ }^{18}$ Seus pais - José Venâncio e Perpétua - foram escravizados

16 Entrevista concedida por Maria Emerenciana Silva, Adalgisa Lima, Lourdes Lima Neves dos Santos e Ana Maria Bonifácio da Silva em 28 maio 2012.

17 Fotografia de Lívia Monteiro. Piedade do Rio Grande, Minas Gerais, Brasil, maio 2012.

18 Entrevista concedida por Maria Emerenciana Silva, Adalgisa Lima, Lourdes Lima Neves dos Santos e Ana Maria Bonifácio da Silva em 28 maio 2012. 
na Fazenda da Vargem, onde o primeiro capitão viveu durante os últimos anos da escravidão. Com a sua primeira esposa, Maria José de Faria, que também nasceu ventre livre e cujos pais foram escravizados na Fazenda do Tejuco, José Venâncio Lima teve dez filhos. Com a segunda esposa, Maria Santana, ele teve sete filhos, entre eles, José Santana de Faria, também membro fundador do grupo.

Figura 5

Diagrama da família do primeiro capitão José Venâncio Lima ${ }^{19}$

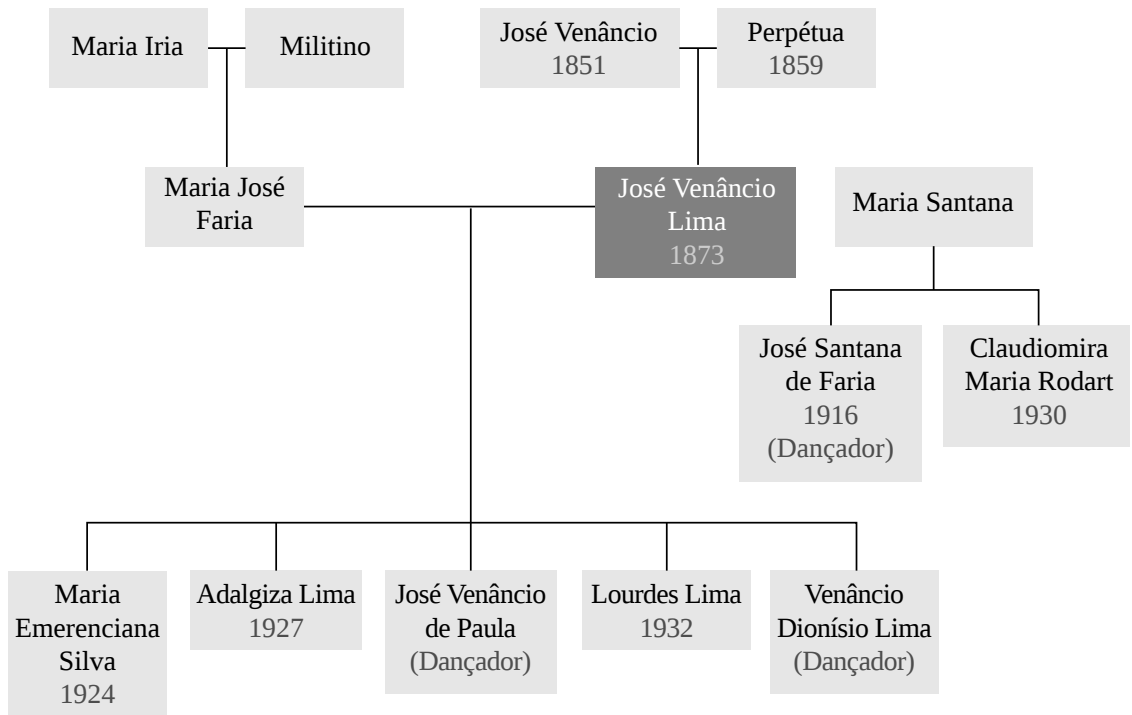

19 O diagrama foi elaborado a partir das entrevistas e pesquisa com a documentação, especialmente: Entrevista concedida por Maria Emerenciana Silva, Adalgisa Lima, Lourdes Lima Neves dos Santos e Ana Maria Bonifácio da Silva em 28 maio 2012. Arquivo da sede do Iphan em São João del Rei, fundo 45, cx. 174, Inventário de Justino Fagundes do Nascimento, 24 jul. 1862. Arquivo Público Mineiro (APM), Belo Horizonte, fundo 34, cx. 6, doc. 18, Relação dos Habitantes da Aplicação de N. S. da Piedade do Rio Grande, 20 maio 1831. Arquivo da sede do Iphan em São João del Rei, fundo 45, cx. 174, Inventário de Custódio Fagundes do Nascimento, 25 mar. 1865. Inventário de Maria Batista Teixeira, 10 abr. 1871; Arquivo da sede do Iphan em São João del Rei, fundo 34, cx. 281, Inventário de Jerônimo Ribeiro do Valle, 28 abr. 1849. Arquivo Eclesiástico da Arquidiocese de Mariana(AEAM), Mariana, MG, fundo 32, cx. 456, Assentos de Batismo da Paróquia de Nossa Senhora da Piedade, 1831. A consulta aos Assentos de Batismo foi realizada pelo site Family Search ש 
Na segunda metade do século XIX, a maioria dos membros dessa família morava nas terras cedidas das fazendas da Vargem e Tejuco, na região de Piedade, onde eram escravizados. Pelo lado paterno de José Venâncio Lima, seu pai José Venâncio de nação, compunha a lista dos escravizados de Justino e Maria Baptista, proprietários da fazenda da Vargem, e teria nascido em 1824. O casamento de José de nação com Perpétua aconteceu na ermida da Fazenda da Vargem, em data desconhecida. ${ }^{20}$

Para Faria, o casamento entre os escravizados dificultava aos senhores o rompimento das relações sociais que os escravizados mantinham, principalmente naquelas áreas onde a Igreja Católica tinha muito domínio, como é o caso de Minas Gerais. ${ }^{21}$ Para Florentino e Góes, a família escrava promovia a socialização, atenuando o cativeiro e os conflitos existentes, tanto entre os próprios escravizados como entre os escravizados e senhores, mantendo a "verdadeira” paz nas senzalas. Slenes afirma que a família escrava permitia importantes ganhos aos escravos, como a habitação diferenciada e, com isso, a escolha da própria organização desse lar. ${ }^{22}$

Para desvendar as histórias das famílias escravas, foi preciso entender o papel das famílias de seus proprietários no século XIX, para o que os inventários e testamentos foram importantes. Entre eles, figuram o

20 Arquivo da sede do Iphan em São João del Rei, fundo 45, cx. 174, Inventário de Justino Fagundes do Nascimento.

21 Sheila de Castro Faria, A colônia em movimento: fortuna e família no cotidiano colonial, Rio de Janeiro: Nova Fronteira, 1998, p. 336.

22 Manolo Florentino e José Roberto Góes, A paz das senzalas: famílias escravas e tráfico atlântico, Rio de Janeiro, c. 1790-c. 1850, Rio de Janeiro: Civilização Brasileira, 1997, pp. 34-47. Robert W. Slenes, "Os múltiplos porcos e diamantes: a economia escrava de Minas Gerais no Século XIX”, Estudos Econômicos, v. 18, n. 3 (1988), pp. 449-495; Robert W. Slenes, "Senhores e subalternos no Oeste Paulista" in Luiz Felipe de Alencastro (org.), História da vida privada no Brasil: Império: a corte e a modernidade nacional, (São Paulo: Companhia das Letras, 1997), p. 78; Robert W. Slenes, Os sons dos negros no Brasil: cantos, danças, folguedos, origens, São Paulo: Art. Ed., 1988, p. 56. 
casal Justino Fagundes do Nascimento ${ }^{23}$ e Maria Baptista Teixeira. ${ }^{24}$ Quando Justino faleceu, em 1862, era dono de terras nas fazendas Bocaina, Ponte Alta, Barreira, Tejuco, Chipotó, Boa Vista e Vargem. ${ }^{25}$ A extensão territorial dessa herança permite que tenhamos um pouco da dimensão da riqueza do casal.

Em quase todas as entrevistas, essas fazendas e seus locais de cultivo e plantio foram lembrados, sugerindo o quanto as memórias da escravidão estão atreladas também aos espaços físicos do trabalho e aos locais de morada dos antepassados escravizados.

Nas narrativas congadeiras-moçambiqueiras, há referências aos locais de morada de seus antepassados, como Corguinho, Gentio, Morro do Chapéu, Tapera, Arião e a outras áreas circunvizinhas às sedes das fazendas, especialmente Vargem, Tejuco e Ribeiro dos Cavalos. O complexo de fazendas escravistas nessa região estava entrelaçado pelos laços existentes entre as famílias senhoriais e as famílias escravas. Especificamente sobre a família do primeiro capitão, suas filhas narraram muitas histórias sobre as fazendas da Vargem e do Tejuco - locais onde seus antepassados foram escravizados.

Na Fazenda da Vargem, os escravizados José Venâncio e Perpétua (pais do primeiro capitão) trabalharam e viveram. Militino e Iria (pais da

23 Justino nasceu em 1815 e foi juiz de paz no distrito de Nossa Senhora da Piedade. Era filho único do capitão Custódio Fagundes do Nascimento e de dona Claudina Maria de Jesus, herdou um patrimônio considerável para a época: culturas da fazenda denominada Tejuco e Bocaina, campos na mesma fazenda, benfeitorias da Fazenda do Tejuco - com quintal e arvoredos -, partes na benfeitoria denominada Vargem do Paiol, um moinho e uma morada de casa situada na capela da Piedade, além de um pequeno terreno. No total, um monte mor de quarenta e dois contos e trezentos e noventa e seis mil réis, além de dezenove escravos. Arquivo da sede do Iphan em São João del Rei, fundo 45, cx. 174, Inventário de Custódio Fagundes do Nascimento, 25 mar. 1865.

24 Maria Baptista Teixeira era filha de Jerônimo Ribeiro do Valle e Francisca Bernardina Teixeira. Nasceu em 1821 e foi batizada em Aiuruoca. Seus pais eram proprietários da Fazenda da Campanha do Rio Grande, fundada antes de 1809, e de mais de quarenta escravos no ano do falecimento de Jerônimo, em 1849. Arquivo da sede do Iphan em São João del Rei, fundo 47, cx. 275, Inventário de Maria Batista Teixeira, 10 abr. 1871; Arquivo da sede do Iphan em São João del Rei, fundo 34, cx. 281, Inventário de Jerônimo Ribeiro do Valle, 28 abr. 1849.

25 Arquivo da sede do Iphan em São João del Rei, fundo 45, cx. 174, Inventário de Justino Fagundes do Nascimento. 
esposa do primeiro capitão) viveram nas terras da Fazenda do Tejuco com seus descendentes, lembrando que a avó Iria era chamada de Bá naquela fazenda. ${ }^{26}$ Havia, portanto, uma complexa rede de relações sociais entre os proprietários dessas fazendas e seus escravizados. Além da proximidade geográfica das fazendas, ambas foram herdadas e, possivelmente com a morte dos antigos proprietários, os escravizados do Tejuco foram para a Vargem e vice-versa. Redes de sociabilidade e solidariedade foram, portanto, estabelecidas entre os senhores e entre seus escravizados.

Com as pistas dadas nas entrevistas, localizei documentos que ajudaram a compor as histórias familiares dos escravizados dessas fazendas. O casal Claudiomira e Bem contaram sobre a "vó Perpétua" (Claudiomira é filha do primeiro capitão José Venâncio com Maria Santana, portanto, é irmã por parte de pai de Maria Emerenciana, Adalgiza e Lourdes). Suas memórias contam que

as mães da gente não pegou cativeiro. A vó Perpétua pegou. Mas ela não era escrava, ela não era castigada, ela foi do tempo do cativeiro, ela tinha carta branca. O patrão não deixava, nunca deixou castigar porque ele gostava dela. Eles contavam que ela ainda insultava as outras porque ela sabia que não ia ser castigada. As outras não podiam reclamar, porque senão apanhava e ela insultava. Eles contavam que quando tinha umas escravas e os patrões gostavam aquela nunca era castigada, eles gostavam né? ${ }^{27}$

Ao contar que sua avó não era castigada - e por isso não era escrava -, Claudiomira classifica o escravo como aquele que apanhava, dotado de sofrimento e vítima das maldades dos senhores. E ia além, pois ela insultava as outras escravas por causa de sua condição privilegiada, afinal, “os patrões gostavam dela”. É possível perceber o quanto a construção da memória familiar a respeito do primeiro capitão e dos seus

26 Entrevista concedida por Maria Emerenciana Silva, Adalgisa Lima, Lourdes Lima Neves dos Santos e Ana Maria Bonifácio da Silva em 28 maio 2012.

27 Entrevista concedida por Claudiomira Maria Rodart e José Custódio, em 6 jun. 2013. 
antepassados perpassa a imagem de uma família com certos privilégios em relação aos outros escravizados.

Desse modo, ao analisar a trajetória e as redes de sociabilidades nas quais essa família estava inserida, compreende-se como esses indivíduos lidaram com o passado escravista, atribuindo-lhe significados diversos e protagonismo frente à organização da Associação de Congada e Moçambique de Piedade nos anos seguintes ao fim da escravidão.

Na família do segundo capitão, João Manoel da Cruz (conhecido como João Lotera), esses laços familiares também foram compreendidos com auxílio da análise documental de famílias senhoriais da região no período (Figura 6).

Figura 6

Diagrama da família do segundo Capitão João Manuel da Cruz ${ }^{28}$

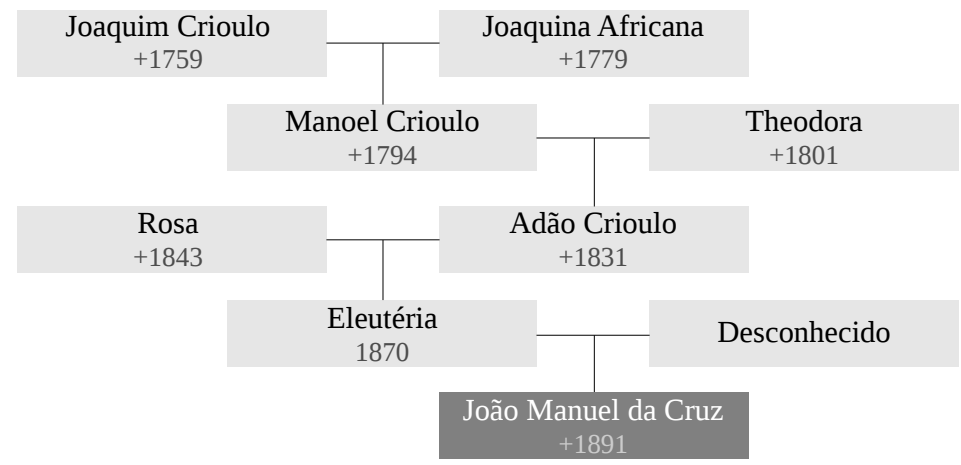

28 O diagrama foi elaborado a partir das entrevistas e pesquisa na documentação, especialmente: Entrevista concedida por Maria Emerenciana Silva, Adalgisa Lima, Lourdes Lima Neves dos Santos e Ana Maria Bonifácio da Silva em 28 maio 2012. Arquivo da sede do Iphan em São João del Rei, fundo 45, cx. 174, Inventário de Justino Fagundes do Nascimento, 24 jul. 1862. Arquivo Público Mineiro (APM), Belo Horizonte, fundo 34, cx. 6, doc. 18, Relação dos Habitantes da Aplicação de N. S. da Piedade do Rio Grande, 20 maio 1831. Arquivo da sede do Iphan em São João del Rei, fundo 45, cx. 174, Inventário de Custódio Fagundes do Nascimento, 25 mar. 1865. Inventário de Maria Batista Teixeira, 10 abr. 1871; Arquivo da sede do Iphan em São João del Rei, fundo 34, cx. 281, Inventário de Jerônimo Ribeiro do Valle, 28 abr. 1849. AEAM, fundo 32, cx. 456, Assentos de Batismo da Paróquia de Nossa Senhora da Piedade, 1831. A consulta aos Assentos de Batismo foi realizada pelo site Family Search ש. 


\section{Famílias escravas provenientes dessas fazendas:}

- Fazenda da Campanha: Joaquim crioulo e Joaquina africana;

- Fazenda do Tejuco: Maria Iria, Militino e Maria José de Faria;

- Fazenda da Vargem: José de nação, Perpétua e Maria José de Faria;

- Fazenda do Ribeirão: Adão, Rosa e Eleutéria.

Da partilha dos bens do casal Justino e Maria Baptista, da Fazenda da Vargem, a filha Delfina Teixeira Monteiro, casada com Ivo José Monteiro, herdou os três escravizados: o casal Adão e Rosa e sua filha Eleutéria (mãe do segundo capitão João Manoel da Cruz), moradores da Fazenda do Ribeirão dos Cavalos. ${ }^{29} \mathrm{~A}$ família escrava do segundo capitão não foi separada no ato da partilha dos bens de Maria Baptista.

Ainda jovem, o escravizado Adão crioulo foi descrito no inventário de Jerônimo Ribeiro do Vale (pai de Maria Batista e avô de Delfina, falecido em 1849) como pagamento feito a sua filha. Junto com o escravizado Adão crioulo, os escravizados Joaquim crioulo, nascido em 1759; Joaquina africana, esposa de Joaquim e nascida em 1779; e seu filho Manoel, nascido em 1794, passaram a pertencer à Maria Baptista, que nessa data já era casada com Justino e vivia na Fazenda da Vargem. ${ }^{30}$

Nas terras da Fazenda da Vargem, Adão conheceu Rosa, escrava crioula que, em 1862, tinha apenas dezenove anos de idade. Em 1871, a família já havia aumentado com os filhos Cristóvão e Eleutéria, com três e dois anos, respectivamente. ${ }^{31}$ Cristóvão foi batizado na ermida da Fazenda da Vargem no dia 4 de outubro de $1868 .{ }^{32}$ Em 1871, a família de Adão e

29 Arquivo da sede do Iphan em São João del Rei, fundo 47, cx. 275, Inventário de Maria Batista Teixeira.

30 Arquivo da sede do Iphan em São João del Rei, fundo 46, cx. 281, Inventário de Jerônimo Ribeiro do Valle.

31 Arquivo da sede do Iphan em São João del Rei, fundo 46, cx. 163, Inventário de Ivo José Monteiro, 10 nov. 1883.

32 AEAM, fundo 32, cx. 456, Assentos de Batismo da Paróquia de Nossa Senhora da Piedade, 1831. A consulta aos Assentos de Batismo foi realizada pelo site Family Search 7. 
Rosa foi viver com o casal Delfina e Ivo nas terras da Fazenda do Retiro, herança da Fazenda do Ribeirão dos Cavalos. No ato da partilha, Cristóvão tornou-se bem do órfão Jerônimo do Nascimento, então menor de idade e tutorado por sua irmã Delfina. Esse fato nos leva a crer que a família não foi separada. Todos esses enlaces familiares nos apresentam uma complexa trama social vivida pelos escravizados no final do século XIX nas fazendas de Piedade.

A pequena Eleutéria aparece nas narrativas contadas por congadeiros-moçambiqueiros, tornando-se "Sá Lotera, uma preta que vivia nas terras do Ivo Velho e Ivo Novo”. ${ }^{33}$ Eleutéria foi mãe de João Manoel da Cruz, fundador e segundo capitão da Congada e Moçambique, conhecido como “João Lotera”. A história familiar do segundo capitão e seus antepassados também se entrelaça com a de proprietários de escravizados na região, como é possível perceber com as histórias do casal Antônio José Monteiro e sua esposa Ignácia Bernardina Teixeira. Eles eram proprietários da Fazenda do Ribeirão dos Cavalos - onde a família de Adão passou a viver -, com mais de 280 alqueires de terras de cultura, além de terras no local chamado Retiro do Gentio - uma morada de casas no arraial da Piedade - e mais de 22 escravizados. ${ }^{34}$

Inácia Bernardina e Maria Baptista, da Fazenda da Vargem, eram irmãs. Dos sete filhos do casal Inácia e Antônio, três filhas casaram-se com filhos do casal Justino e Maria Batista. Enlaces matrimoniais são considerados pela historiografia como estratégias de alianças, ao unir ramos da parentela de prestígio social que as famílias possuíam. Para Silvia Brugger, numa sociedade escravista, o princípio da igualdade social e jurídica entre os nubentes pautava os critérios de escolhas matrimoniais. ${ }^{35}$

33 Entrevista concedida por Claudiomira Maria Rodart e José Custódio, em 6 jun. 2013. 34 Arquivo da sede do Iphan em São João del Rei, fundo 56, cx. 327, Inventário de Inácia Bernardina Teixeira, 31 jun. 1865; Arquivo da sede do Iphan em São João del Rei, fundo 67, cx. 163, Inventário de Antônio José Monteiro, 24 fev. 1871.

35 Silvia Maria Jardim Brugger, Minas patriarcal: família e sociedade (São João del Rei séculos XVIII e XIX), São Paulo: Annablume, 2006, p. 230. 
Essas famílias de proprietários escravistas que se estabeleceram na região - principalmente na primeira metade do século XIX - no final desse século já estavam enraizadas. As alianças matrimoniais estabelecidas (Figura 7) promoviam ainda mais o enraizamento e faziam com que suas fortunas, principalmente os escravizados, permanecessem em família. Ao detectar as redes parentais dos senhores, conseguimos identificar também as redes parentais de seus escravizados, que iam além das fazendas onde residiam. ${ }^{36}$

\section{Figura 7}

Redes de parentescos entre as famílias senhoriais ${ }^{37}$

Fazenda da Campanha

Jerônimo Ribeiro do Valle e

Francisca Bernardina Teixeira
Fazenda do Tejuco

Custódio Fagundes do Nascimento

e Joaquina Marina de Jesus

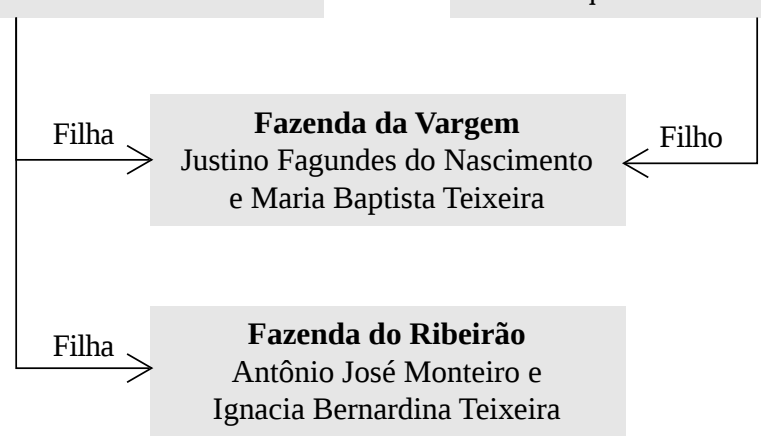

36 Brugger, Minas patriarcal, p. 235.

37 O diagrama foi elaborado a partir das entrevistas e pesquisa na documentação, especialmente: Entrevista concedida por Maria Emerenciana Silva, Adalgisa Lima, Lourdes Lima Neves dos Santos e Ana Maria Bonifácio da Silva em 28 maio 2012. Arquivo da sede do Iphan em São João del Rei, fundo 45, cx. 174, Inventário de Justino Fagundes do Nascimento, 24 jul. 1862. Arquivo Público Mineiro (APM), Belo Horizonte, fundo 34, cx. 6, doc. 18, Relação dos Habitantes da Aplicação de N. S. da Piedade do Rio Grande, 20 maio 1831. Arquivo da sede do Iphan em São João del Rei, fundo 45, cx. 174, Inventário de Custódio Fagundes do Nascimento, 25 mar. 1865. Inventário de Maria Batista Teixeira, 10 abr. 1871; Arquivo da sede do Iphan em São João del Rei, fundo 34, cx. 281, Inventário de Jerônimo Ribeiro do Valle, 28 abr. 1849. AEAM, fundo 32, cx. 456, Assentos de Batismo da Paróquia de Nossa Senhora da Piedade, 1831. A consulta aos Assentos de Batismo foi realizada pelo site Family Search ש. 
Em relação à separação das famílias escravas após a morte dos antigos senhores, consegui identificar que a família de Justino e Maria Batista mantiveram, quase sempre, as famílias escravas unidas. Um panorama um pouco diferente dessa situação pôde ser encontrado na fazenda vizinha, do Ribeirão dos Cavalos, de Antônio José Monteiro e Ignácia Bernardina Teixeira.

No que tange especialmente às famílias escravas analisadas, aquelas dos futuros capitães da Congada e Moçambique, todas as gerações localizadas conseguiram se manter unidas enquanto perdurou a escravidão naquelas terras. $\mathrm{E}$ isso deve ter feito a diferença para esses grupos familiares, tornando-os, possivelmente, lideranças entre os escravizados e criando hierarquias sociais típicas de uma sociedade escravista.

Hebe Mattos foi categórica ao afirmar que a formação das famílias escravas gerava uma diferenciação entre eles e era uma experiência de liberdade, pois "casar elitizava os cativos". As escolhas feitas pelos escravizados em relação à formação de suas famílias e aos fatores que sobrevinham sobre suas opções perpassavam a hierarquia social vigente na segunda metade do século XIX. ${ }^{38}$

Constituir família tinha diversos significados para os escravizados. Podemos citar a estratégia de socialização e também o aumento das redes de solidariedade; a possibilidade de acesso à terra e moradia separada; a formação de uma comunidade escrava, como foi o caso das famílias dos primeiros capitães da Congada e Moçambique, por exemplo. ${ }^{39}$ Suas redes de solidariedade eram fortes e as relações sociais mantidas passavam ora por momentos de incertezas e fracassos, ora por ganhos e conquistas. Conforme Mattos, as relações familiares cativas estavam associadas a uma experiência dentro do cativeiro que remete às expectativas de liberdade dos escravizados. ${ }^{40}$

38 Hebe Maria Mattos, Das cores do silêncio: os significados da liberdade no Sudeste escravista, Brasil século XIX, $3^{\text {a }}$ ed., Campinas: Unicamp, 2013, pp. 56-67.

39 Slenes, "Os múltiplos porcos e diamantes”, pp.449-495; "Senhores e subalternos no Oeste Paulista”, p. 271. Os sons dos negros no Brasil, pp. 34-40.

40 Mattos, Das cores do silêncio, p. 77. 
As famílias de Adão, Rosa, Perpétua, José e seus filhos e filhas se entrelaçam, assim como as famílias de Justino, Maria Batista, Antônio e Ignácia, seus filhos, filhas, genros, noras e netos também. É possível que as famílias escravas tivessem obtido alguns ganhos materiais e simbólicos, como o fato de nunca terem sido separadas e a possibilidade de organização e liderança frente à Associação congadeira no imediato pós-Abolição.

Foram essas famílias negras e seus descendentes que fundaram na década de 1920 a Associação de Congada e Moçambique de Piedade do Rio Grande, com símbolos, rituais e devoções ligadas às memórias da escravidão e da liberdade e aos aprendizados congadeiros-moçambiqueiros vinculados à Irmandade do Rosário de Ibertioga.

\section{Irmãos de fé: a Irmandade do Rosário e os caminhos para Ibertioga}

É, foi meu pai que fundou. Então, foi assim. Tinha a festa do Barroso, né? E vinha dançar na Ibertioga. Então, meu pai foi à festa da Ibertioga e viu eles dançando. E o senhor chamava João Eugênio, que era o capitão, e eles ficaram conversando. Aí o senhor João Eugenio convidou ele, falou assim então: 'Quando for ano que vem, vocês vem dançar junto'. Aí meu pai dançou acho que uns três ou quatro anos, não sei. E estavam meus irmãos já assim todos mocinhos, igual esses meninos que dança aí. Aí meu pai levou meus irmãos para dançar, então, eles começaram a dançar. Aí, depois disso, o meu pai formou então esse grupo de Congado [de Piedade] ${ }^{41}$

Maria Emerenciana Lima narrou em 2012 as motivações do seu pai, o primeiro capitão José Venâncio, para fundar e iniciar as festas da

41 Entrevista concedida por Maria Emerenciana Silva, Adalgisa Lima, Lourdes Lima Neves dos Santos e Ana Maria Bonifácio da Silva em 28 maio 2012. 
Congada e Moçambique de Piedade. Ela e todos os outros depoentes entrevistados pontuam e explicam a fundação da Congada e Moçambique de Piedade com referências às danças e festas da Congada de Ibertioga, cidade vizinha. Na narrativa do neto de José Venâncio, João Damasceno de Faria, e de outros congadeiros-moçambiqueiros entrevistados, as cidades de Ibertioga e Barroso também são citadas enquanto referências para a fundação da Congada e Moçambique de Piedade.

Como foi possível analisar pelo inventário de Justino, dono da Fazenda da Vargem, no seu falecimento em 1862, ele deixou uma dívida à Irmandade do Rosário de Ibertioga. As duas famílias escravas dos antepassados dos dois primeiros capitães da Congada e Moçambique pertenceram a esse senhor e viveram nas terras dessa fazenda. Assim, é possível inferir que, possivelmente, os membros dessas famílias escravas frequentaram essa irmandade em Ibertioga. Esse fato explica, ainda mais, os elos entre o passado congadeiro-moçambiqueiro com a cidade de Ibertioga e os aprendizados advindos da participação em irmandades do Rosário do século XIX.

O arraial de Ibertioga, no século XIX, pertencia à "freguesia da nobre e muito leal cidade de Barbacena, comarca do Rio Paraibuna, bispado de Mariana” e nesse século foi fundada a Irmandade do Rosário dos Pretos e uma capela. ${ }^{42}$ Julita Scarano destacou que uma das primeiras e mais importantes devoções com a qual se identificaram os negros foi a de Nossa Senhora do Rosário - protetora dos "homens pretos". ${ }^{43}$ Para John Thornton, o catolicismo africano - "um conjunto de ideias religiosas semelhantes entre cristianismo e religiões africanas" - permitiu que os africanos se apropriassem dos santos católicos, relacionando-os às divindades africanas no Brasil colonial e imperial. ${ }^{44}$

42 AEAM, num. 4057, Compromisso da Irmandade, 1843.

43 Julita Scarano, Devoção e escravidão: a irmandade do Rosário dos Pretos no distrito Diamantino no século XVIII, 2a ed., São Paulo: Editora Nacional, 1978, p. 48.

44 John Thornton (1998) apud Anderson José Machado de Oliveira, Devoção negra: santos pretos e catequese no Brasil colonial, Rio de Janeiro: Quartet; Faperj, 2008, p. 27. 
No Compromisso da Irmandade do Rosário de Ibertioga consta:

No arraial de Ibertioga erigirão devotamente uma capela a senhora do Rosário e para a devoção e fique permanecendo os sagrados cultos da senhora farão o presente compromisso regido de todo o benefício de suas almas no que vossa majestade imperial, e por isso esperam a confirmação dos seguintes estatutos que o formalizam. ${ }^{45}$

No capítulo sete do mesmo documento, intitulado "dos irmãos que haverá nessa irmandade”, constam os valores pagos para a entrada na irmandade, assim como os valores anuais que cada irmão deveria pagar: "Pagando cada um de entrada mil e duzentos reis em cada ano de anual seis contos de reis”. O valor pago para que algum irmão entrasse na Irmandade do Rosário dos Pretos de Ibertioga é o mesmo que Justino ficou devendo quando faleceu. Possivelmente, o juiz de paz pagava a entrada de seus escravizados nessa irmandade. ${ }^{46}$

As irmandades do Rosário instituídas em Minas Gerais, no período colonial e imperial, são bastante numerosas e expressivas de acordo com Célia Borges. ${ }^{47}$ Os reis e rainhas pertenciam a diferentes grupos étnicos e eram de diferentes procedências. Ser rei conferia prestígio, mesmo a um escravo, por ser reconhecido não só junto dos seus pares como frente à comunidade. Ainda para a autora, havia diversos rituais e a participação de diferentes grupos, portanto, não se tratava de uma representação direta do reino do Congo em terras coloniais, mas era, antes de tudo, uma "representação do novo grupo reconstruído na situação colonial. Mesmo porque em Minas os irmãos provenientes do Congo nem sempre constituíram a maioria das confrarias”. ${ }^{48}$ As festas do Rosário, realizadas

45 AEAM, num. 4057, Compromisso da Irmandade, 1843.

46 AEAM, num. 4057, Compromisso da Irmandade, 1843.

47 Célia Maia Borges, Escravos e libertos nas Irmandades do Rosário: devoção e solidariedade em Minas Gerais, século XVIII e XIX, Juiz de Fora: Editora da UFJF, 2005, p. 177.

48 Borges, Escravos e libertos, pp. 177-180. 
pelas irmandades do Rosário, mesclavam missas, procissões, cerimônia de coroação dos reis, banquete e várias representações dramáticas que, de acordo com Célia Borges e Marina de Mello e Souza, são conhecidas como Congado por conta da eleição dos "reis do Congo".

As festas da Irmandade do Rosário de Ibertioga certamente seguiam esses rituais e a participação dos escravizados da Fazenda da Vargem provavelmente acontecia. Foi a partir desse contato que as famílias escravas analisadas “aprenderam” a saudar Nossa Senhora do Rosário.

As irmandades negras têm variedade de santos de devoção, como Nossa Senhora do Rosário, Santo Elesbão, São Benedito, Santa Efigênia, Santo Antônio e outras, mas o culto a Nossa Senhora do Rosário é o mais recorrente entre as irmandades compostas pelos escravizados, que, para além dos laços criados entre os irmãos, constituíam local de vivência religiosa, onde tradições africanas e portuguesas caminhavam juntas.

Anderson Oliveira afirma que, especialmente nas irmandades de Santo Elesbão e Santa Efigênia, no século XVIII, o culto aos santos era um dos fatores de construção de identidades entre a população negra no Brasil colonial. ${ }^{49} \mathrm{O}$ historiador defende que a Igreja Católica estimulava o culto como estratégia de conversão de africanos e seus descendentes, mas que estes resistiam e reinterpretavam os códigos católicos. Através das irmandades religiosas, a população negra no Brasil colonial e também imperial, escravizados africanos, escravizados nascidos no Brasil e livres reconstruíram suas identidades e reinterpretaram os códigos católicos, conquistando relativa autonomia para praticarem seus cultos.

As irmandades negras desses períodos se formavam em torno das identidades africanas mais amplas, criadas na diáspora negra. ${ }^{50} \mathrm{E}$ uma das

49 Anderson José Machado de Oliveira, “Devoção e identidades: significados do culto de Santo Elesbão e Santa Efigênia no Rio de Janeiro e nas Minas Gerais no Setecentos”, Topoi, Revista de História, v. 7, n. 12 (2006), pp. 60-115.

50 Para uma discussão em torno das questões da diáspora negra, cf.: Colin Palmer, "Defining and Studying the Modern African Diaspora”, The Journal of Negro History, v. 85, n. 1-2 (2000), pp. 27-32. Stuart Hall, Da diáspora, identidades e mediações culturais, Belo Horizonte; Brasília: Universidade Federal de Minas Gerais; Unesco Brasil, 2003. 
principais atividades dessas irmandades era "a promoção da vida lúdica, ou estabelecer o estado de folia de seus membros e da comunidade negra em geral [...] os africanos reviviam simbolicamente suas antigas tradições culturais e consolidavam na prática novas identidades étnicas”. ${ }^{51}$

Em relação aos "reis negros no Brasil escravista” e suas festas, Marina de Mello e Souza afirma que o momento das eleições representava o processo de recriação de tradições onde mesclavam fragmentos de uma memória africana e elementos da cultura católica portuguesa. ${ }^{52}$ Para ela, a coroação e a realeza representam, dentro das irmandades, a constituição de identidades africanas, pois há a recuperação dos traços das identidades tribais, dos laços e das linhagens.

Apesar de não ter conseguido localizar a lista de irmãos participantes da Irmandade do Rosário de Ibertioga, ao que tudo indica, os antepassados dos congadeiros-moçambiqueiros de Piedade frequentavam essa irmandade e mantinham um trânsito eumalinguagem religiosa comum, comopartedasestratégias de resistência à escravidão. Através dessa linguagem, os escravizados alcançaram espaços de autonomia e criaram laços de solidariedade e sociabilidade - aprendizados importantes para serem congadeiros-moçambiqueiros.

As famílias escravas, especialmente dos primeiros capitães, eram ligadas às irmandades que estavam sob a proteção de uma determinada família senhorial. Isso era uma diferenciação social que rendeu dividendos no pós-abolição, apesar dos intensos conflitos e incertezas advindas com o processo abolicionista.

\section{Conflitos e tensões nas últimas décadas do século XIX}

O órfão Ivo se acha com dezessete anos e tendo orientação para o comércio empregou-se em Barbacena, e hoje se acha em casa

51 João José Reis. "Identidade e diversidade étnicas nas irmandades negras no tempo da escravidão”, Tempo, v. 2, n. 3 (1997), pp. 7-33.

52 Mello e Sousa, Reis negros no Brasil escravista, pp. 47-55. 
empregado na lavoura visto que há falta de braços e o isolamento em que ficaram os fazendeiros com a estirada dos ex-escravos. ${ }^{53}$

O trecho acima foi encontrado nas páginas amareladas do inventário post-mortem do senhor Ivo José Monteiro, conhecido como Ivo Velho, proprietário da Fazenda do Ribeirão dos Cavalos e dos escravizados Adão, Rosa e Eleutéria (membros da família do segundo capitão, João Lotera). Com o falecimento de Ivo Velho, em 1883, seu filho homônimo, Ivo Nascimento Monteiro, conhecido como Ivo Novo, herdou as terras e também os "problemas” que o fim da escravidão começou a criar para os proprietários da região.

As décadas de 1870 e 1880 assistiram ao fim do sistema escravista, por mais que muitos fazendeiros tentassem "desesperadamente se agarrar aos aspectos residuais da instituição". ${ }^{54}$ Os debates políticos travados dentro do governo imperial nos dão conta de que algumas iniciativas promoviam a abolição, mesmo que de forma gradual. A implementação da chamada Lei do Ventre Livre, de 28 de setembro de 1871, é uma dessas formas, pois ela garantia que os filhos de escravos nascidos após essa data estariam livres e também instituía o fundo de emancipação, “a matrícula obrigatória dos cativos, medida que visava maior controle fiscal sobre os proprietários. O escravo que não fosse matriculado poderia ser considerado livre pelas autoridades sem o desembolso de qualquer quantia". ${ }^{55}$

Como bem destacou Chalhoub, a lei reconhecia vários direitos que os escravizados já tinham adquirido por meio das relações costumeiras estabelecidas com seus senhores, além de dar permissão aos escravos para acionar a justiça, caso os senhores se recusassem a dar alforria, mesmo

53 Arquivo da sede do Iphan em São João del Rei, fundo 46, cx. 163, Inventário de Ivo José Monteiro, 10 nov. 1883.

54 Seymour Drescher, Abolição. Uma história da escravidão e do antiescravismo. Trad. Antonio Penalves Rocha, São Paulo: Editora da Unesp, 2011, p. 525.

55 Fraga Filho, Encruzilhadas da Liberdade, p. 58. 
com o pecúlio do escravo. ${ }^{56}$ Alguns recortes de jornais de São João del Rei, cidade próxima a Piedade, dos anos finais da escravidão, indicam que havia uma onda contrária ao movimento abolicionista em curso na região. Em 9 de dezembro de 1880, a capa do jornal O Arauto de Minas, monarquista e conservador, trazia: "Não há no Brasil quem advogue a causa da escravidão. Todos concordam em reconhecer a necessidade e conveniência de acabar-se com essa fatal instituição [...]. A abolição do elemento servil no Brasil está resolvida pela lei de 28 de setembro de 1871”. ${ }^{57}$

Além de reverenciar a lei 1871, considerando-a como a resolução de um problema e que teria colocado fim à escravidão no Brasil - por aboli-la de forma lenta e gradual -, o texto apresenta também o discurso do deputado representante da província de Minas na Câmara, Martinho Campos. Ele considerava ofensivas as propagandas abolicionistas, “que só visam fazer figura perante o estrangeiro”, de acordo com o jornal. Isso indica que, na última década da escravidão, ocorreu um grande embate de ideias contrárias e favoráveis à escravidão, que reverberaram e circularam de maneiras distintas nas regiões do país. Havia uma opinião pública sendo gestada sobre o tema, assim como era percebido por muitos fazendeiros da região, leitores desses jornais. ${ }^{58}$

Não foi possível identificar se algum fazendeiro de Piedade era favorável ou não à campanha abolicionista. Contudo, é provável que as ideias abolicionistas, suas propagandas, bem como as campanhas contrárias, circulassem nas fazendas de Piedade e estivessem presentes na região.

$\mathrm{Na}$ análise de Silva, os jornais abolicionistas de São João del Rei debateram a crise do escravismo com um discurso paternalista. ${ }^{59} \mathrm{O}$ Arauto de Minas publicou em maio de 1889: “o povo desta cidade é francamente

56 Sidney Chalhoub, Visões da Liberdade: uma história das últimas décadas da escravidão na Corte, São Paulo: Companhia das Letras, 1990, p. 181.

57 O Arauto de Minas, São João del Rei, MG, 9 dez. 1880, p. 8, ש.

58 Vale mencionar que encontrei dois exemplares do jornal O Arauto de Minas na fazenda da Vargem, cujos proprietários eram Justino e Maria Batista.

59 Denilson de Cássio Silva, “O drama social da abolição: escravidão, liberdade, trabalho e cidadania em São João del Rei (1871-1897)”, Dissertação (Mestrado em História), Universidade Federal Fluminense, Niterói, 2011, p. 251. 
devotado à monarquia e cioso de suas convicções não permite que se lhes toque de leve. Quem não é daqui, o que faz aqui?”. ${ }^{60}$ Demonstrando o clima possivelmente tenso vivido em São João del Rei e também na região vizinha nos anos finais da escravidão. Ao desqualificar os republicanos, por não serem naturais de São João, o texto aponta o quanto era importante, para as principais famílias da região, o pertencimento e o enraizamento no local - algo que pode ser considerado próximo às principais famílias escravistas aqui analisadas.

Os dois capitães e outros fundadores da Congada e Moçambique, além de seus aparentados, passaram toda a infância, adolescência e parte de suas vidas nessa conjuntura e ambiência política. Nasceram livres, mas conviveram por mais de quinze anos com o regime escravista, com seus pais, avós, tios, primos e padrinhos sendo escravizados. Além do convívio com fazendeiros, homens livres e pobres, vizinhos etc. Esse grupo teve que fazer escolhas e negociar cotidianamente espaços e ganhos sociais nessa sociedade hierárquica e desigual.

Além dos projetos de liberdade, a fase final do regime escravista também foi marcada por tensões e conflitos na região de Piedade entre senhores e escravizados e isso deixou marcas nas memórias dos descendentes dos escravizados, como foi possível perceber pelas entrevistas realizadas ao longo dessa pesquisa. Dessa maneira, busquei na análise da documentação policial alguns episódios relacionados aos conflitos envolvendo outros ramos das famílias senhoriais analisadas nas últimas décadas da escravidão.

Por volta das onze horas da manhã do dia 11 de abril de 1888, os escravizados João Manoel Felipe, roceiro e carreiro, com 22 anos de idade, e Clemente, roceiro com 28 anos de idade, teriam armado uma emboscada para o seu senhor, Venâncio Teodoro de Andrade. Nesse conflito, João teria atirado no senhor. O caso foi parar na justiça e, após apelação, o réu João Manoel foi absolvido, pois estaria mentindo ao confessar o

60 Apud Brugger, Minas patriarcal, p. 34. 
crime, impelido por outra pessoa. Não consta no documento a sentença do escravo Clemente, apontado como cúmplice de João. ${ }^{61}$

O senhor Venâncio Teodoro de Andrade era casado com Ana Bernardina Teixeira Nascimento, filha do casal Justino e Maria Batista. Os escravizados João Manoel e Clemente foram acusados de cometer o crime contra a pessoa do seu senhor, considerado muito grave na sociedade escravocrata. Além disso, outro ponto nos chama atenção: o crime aconteceu em abril de 1888, ou seja, pouco antes da assinatura da Lei Áurea. Ao que tudo indica, as relações estavam conflituosas nas terras pertencentes a esse ramo familiar. Ainda é possível sugerir que, pelo enraizamento de ambas as famílias na região, tanto dos senhores, como dos escravizados, esse episódio deve ter sido anunciado entre os conhecidos.

Anos antes, um conflito envolveu o senhor Antônio José Monteiro e seus escravizados. Por meio do processo de autuação, encontramos o casal de escravizados Rafael Eugênio de Freitas e Joana Francisca - ele era crioulo, roceiro e jornaleiro, com 30 anos de idade; ela, oriunda da freguesia do Turvo (atual cidade de Andrelândia, próximo a Piedade), costureira e fazia trabalhos caseiros, e também tinha 30 anos - ambos foram acusados de roubo. Ao que consta, o escravo Saluino, pertencente ao alferes Antônio José Monteiro, roubava porcos, galinhas e outros mantimentos e os entregava a Rafael e Joana Francisca. Ainda consta que Saluino vendia os produtos do seu roubo por preços baixos. Antes de os réus irem a júri, o proprietário Antônio José Monteiro retirou todas as queixas contra os réus, pois "estava satisfeito com a pena de prisão e livramento que os réus estavam sofrendo”. 62

Como afirmam Rios e Mattos, "ser um bom senhor era cada vez mais difícil no fim da escravidão”, e, de fato, as duas últimas décadas da escravidão intensificaram os conflitos, as tensões e até mesmo as infrações dos escravos. ${ }^{63}$ Em todas as fazendas analisadas - Vargem, Tejuco,

61 Museu Regional de São João del Rei, PC 55-02 D-148, Inquérito Policial, 1888.

62 Museu Regional de São João del Rei, PC 2830C-16-14, Autuação, 1884.

63 Ana Lugão Rios e Hebe Maria Mattos, Memórias do cativeiro: família, trabalho e cidadania no pós-abolição, Rio de Janeiro: Civilização Brasileira, 2005, p. 184. 
Ribeirão dos Cavalos, Retiro, entre outras -, as escravarias eram antigas e os escravizados viviam em situações de parentesco diversos, com muitos direitos costumeiros já adquiridos.

No inventário do alferes Antônio José Monteiro (proprietário da Fazenda do Ribeirão), há uma carta datada de 1876. Por meio dela pude mapear pequenos rastros que apontam para uma crise do escravismo na região. Por exemplo, a informação da fuga e sumiço por mais de oito meses do escravo Simplício e a preocupação dos proprietários em manter a reprodução escrava: "que o filhinho da escrava Eugênia, Pedro faleceu” e "diga a ele que a Eugênia e a Suzana têm tido muitos abortos e que estão agora elas as duas grávidas, a Eugênia depois do Pedro já teve dois abortos, e peço para lá arranjar com nosso amigo e parente Ivo a dois dos escravos que cá estão”. Além dessa preocupação em manter a reprodução natural do cabedal, a carta finaliza: “o amigo de lá arranjar com ele dois ou quatro escravos machos, não quero mulher”. ${ }^{64}$

A carta aponta para o quanto a reprodução escrava, muito utilizada durante praticamente todo o período escravista na região, começava também a ser considerada um problema devido à escassez da mão de obra escrava. Através dessa carta, pude constatar alguns pontos a respeito das fugas dos escravizados nesse período. O escravo Simplício aparece na lista de bens arrolados no inventário, portanto, ele provavelmente foi capturado. Seu nome aparece também nos registros de batismos de suas filhas, em 1871, o que indica que ele já pertencia à família fazia algum tempo. As fugas, nesse período final da escravidão, podem significar o quanto a crise, que envolvia a mão de obra escrava, tomava conta da região.

Porém, mesmo com esse clima tenso, localizei recibos de compra e venda de escravizados em arquivos pessoais dos descendentes dessas famílias fazendeiras. Datados de 1884, os recibos são passados da cidade

64 Arquivo da sede do Iphan em São João del Rei, fundo 46, cx. 163, Inventário de Ivo José Monteiro, 10 nov. 1883. 
vizinha Ibertioga para Piedade ${ }^{65}$ - isso demonstra a dependência e a necessidade desses fazendeiros em relação à mão de obra escrava, mesmo com as portas desse sistema quase sendo fechadas.

Desse modo, apesar de não ter localizado os conflitos entre as famílias dos primeiros capitães analisadas neste artigo e especialmente com as famílias senhoriais, foi possível perceber que as últimas décadas da escravidão em Piedade foram palco também de tensões envolvendo outras famílias senhoriais e seus escravizados. Mesmo com as redes de proteção e estratégias que algumas dessas famílias tinham - como é possível perceber com as famílias analisadas -, muitos dos conflitos ainda existiam e demonstram o quanto a escravidão foi duramente sentida, resistida e negociada pelos escravizados e libertos.

\section{Considerações finais}

"Foi quando estava acabando o tempo dos escravos. A minha vó ganhou ele [João Venâncio] quando ela era escrava. Ele era criança”, ${ }^{66}$ afirmou Maria Emerenciana, filha do primeiro capitão, quando falava das famílias escravas e libertas que originaram as famílias congadeiras-moçambiqueiras no pós-abolição. Essas famílias extrapolaram os núcleos primários e depois ampliaram suas relações para o parentesco, o compadrio e o ritual - mantidos através da participação na Irmandade do Rosário de Ibertioga -; os elos com o passado ficaram marcados nos rituais, festejos, danças e músicas dos congadeiros-moçambiqueiros do tempo presente.

Havia uma intrínseca rede de relações sociais entre os atores analisados, fossem eles escravizados, senhores ou pobres livres.

65 Recibo de compra e venda de escravo de 8 maio 1884, localizado na residência de Mira Monteira, herdeira da fazenda da Vargem e minha avó.

66 Entrevista concedida por Maria Emerenciana Silva, Adalgisa Lima, Lourdes Lima Neves dos Santos e Ana Maria Bonifácio da Silva em 28 maio 2012. 
A experiência comum do passado escravista dessas famílias em destaque - principalmente dos dois futuros capitães, José Venâncio e João Lotero - foi negociada e conquistada, alcançando uma experiência mais ampla, de descendentes de escravizados para “filhos do Rosário” na região de Piedade.

As histórias familiares dos primeiros capitães da Congada e Moçambique de meados do século XIX demonstram que, com silenciamentos, permanências e transformações, as heranças do passado escravista deixaram marcas em seus filhos(as), netos(as) e aparentados.

Assim, a herança da escravidão, deixada pelas famílias escravas e livres que viveram no final do século XIX na região, foi passada para seus filhos e foi no pós-abolição que as memórias da escravidão e da liberdade se mantiveram presentes e vivas por meio das festas do Rosário - sendo ainda revividas no presente, através das gerações atuais. Essas são compostas, em grande medida, por jovens negros que descendem das famílias fundadoras, que afirmam suas identidades negras e lidam com as mudanças e transformações inerentes a seu próprio tempo. São os responsáveis por narrar o passado nos três dias de festa, com orgulho por fazer “a melhor festa na cidade” e transformar em luta política contemporânea aquilo que seus familiares iniciaram em fins do século XIX.

Todos os ensinamentos do Reinado estão estruturados a partir do núcleo familiar a que cada congadeiro-moçambiqueiro pertence. Em torno de famílias extensas, o Congado e o Moçambique de Piedade estão estruturados no tempo presente - como foi no passado com as redes de relações que ultrapassaram os limites do parentesco. Os núcleos originais, provenientes das famílias do primeiro capitão e de outras, expandiram suas relações e a herança familiar é o aspecto central na perpetuação do grupo de Piedade do Rio Grande.

Para João Damasceno de Faria e Ana Maria Bonifácio da Silva, netos do primeiro capitão José Venâncio, que participam ativamente da Festa de Maio, os significados sobre o Reinado são muitos. Para Joãozinho, 
como é conhecido: "Fora de Piedade tem tudo quanto é tipo de Congada, aqui é diferente. Daqui é a origem”, ${ }^{67}$ E Ana completa:

A Congada é uma tradição africana, vem desde os tempos dos escravos, que meu avô, no caso, conseguiu reviver isso já desde os tempos dele, e aqui na Piedade, é uma coisa que ainda tá viva e é um folclore. O folclore brasileiro pra nós é africano, mas é o folclore brasileiro igual antes a gente estava falando que não pode misturar, mas agora mistura porque tem a congada, que é a dança dos escravos e dos negros. ${ }^{68}$

Atualmente, a Festa de Maio passa por um processo de transformação, tornando-se um patrimônio cultural herdado e reconstruído pelos congadeiros-moçambiqueiros que reafirmam politicamente suas trajetórias históricas enquanto descendentes de escravizados e ganham, cada vez mais, visibilidade e novas perspectivas de engajamento na luta contra o racismo.

Recebido em 30 jan. 2020

Aprovado em 5 out. 2020

doi: 10.9771/aa.v0i62.35294

67 Entrevista concedida por João Damasceno de Faria em 30 maio 2012.

68 Entrevista concedida por Maria Emerenciana Silva, Adalgisa Lima, Lourdes Lima Neves dos Santos e Ana Maria Bonifácio da Silva em 28 maio 2012. 
O objetivo deste artigo é analisar as redes familiares dos antepassados dos dois primeiros capitães da Associação de Congada e Moçambique de Nossa Senhora do Rosário e Nossa Senhora das Mercês nas últimas décadas da escravidão em Piedade do Rio Grande, Minas Gerais. Pretende-se apresentar as alianças, conflitos, negociações e estratégias encontradas por essas famílias escravas e libertas, bem como os caminhos percorridos no aprendizado devocional ligado à Irmandade do Rosário, na cidade vizinha a Piedade, Ibertioga. Os descendentes das famílias dos dois capitães buscaram, desde o pós-Abolição até o tempo presente, ressignificar o passado escravista vivido pelos seus parentes e comemorar a liberdade, através dos cantos, ritmos, danças, músicas e performances realizadas nas festas de Congada e Moçambique - também conhecidas como festas de maio - ao longo dos últimos noventa anos. Por fim, busca-se demonstrar que "foi quando estava acabando o tempo dos escravos” que a última geração do cativeiro de Piedade, entre escravos e livres, deixou como legado às gerações futuras as experiências sentidas e sofridas no tempo da escravidão, com as redes de proteção e os conflitos inerentes a esse período.

Famílias escravas | Libertos | Escravidão | Minas Gerais

\section{“It Happened When Slavery Was Ending": Devotion, Family Networks and Conflicts During the Final Decades of SlaVery in Minas Gerais}

This article analyzes the family networks created by the ancestors of the two first captains of the Associação Congada e Moçambique de Nossa Senhora do Rosário e Nossa Senhora das Mercês during the last decades of slavery in Piedade do Rio Grande, Minas Gerais, Brazil. I show the alliances, conflicts, negotiations and strategies utilized by the families of slaves and freed people, as well as the paths taken in devotional learning at the Irmandade do Rosário, in Ibertioga, a nearby city. From the Post-Abolition period until the present, the two captains'descendants have sought to resignify the history of slavery experienced by their relatives, celebrating their freedom through songs, rhythms and dances performed during the Congada e Moçambique celebrations (also known as the "May Festivities"). Lastly, I argue that "when slavery was ending" in Piedade, the last generation to live through those times, both enslaved and freed people, left their experience of suffering as a legacy for the future generations, including the networks of protection and conflicts inherent to that period.

Enslaved families | Freed people | Slavery | Minas Gerais 